\title{
Histological changes of the liver and metabolic correlates in ewes with pregnancy toxemia
}

[Alterações histológicas do fígado e correlações metabólicas em ovelhas com toxemia da prenhez]

\author{
L. Cal $^{1}$, C. Borteiro ${ }^{1}$, A. Benech ${ }^{1}$, E. Rodas ${ }^{1}$, M.N. Abreu ${ }^{1}$, J. C. Cruz ${ }^{1}$, J. R. González Montaña ${ }^{2}$ \\ ${ }^{1}$ Facultad de Veterinaria, Universidad de la República \\ Lasplaces 1550 - CP 11600 \\ Montevideo - Uruguay \\ ${ }^{2}$ Facultad de Veterinaria - Universidad de León - León, España
}

\begin{abstract}
The histological changes of the liver in ewes with pregnancy toxemia were characterized. Ten ewes were fed on grass ad libitum, and another ten were starved from day 130 of pregnancy for up to four days. Liver puncture biopsies were performed at days 70, 100, 130, and 140 of pregnancy, and at day 45 in postpartum. Seric hydroxybutyrate (HB), non-esterified fatty acids (NEFA), aspartate aminotransferase, and alkaline phosphatase were dosed. Histological preparations revealed similar incidence and intensity of mild liver steatosis in both groups at day 130. Starved ewes become toxemic (as indicated by HB), and at day 140 exhibited more severe injury in a higher proportion (9/9 vs. 4/10; $\mathrm{P}<0.01)$. Almost all of them (7/9) had large amounts of small lipid droplets in almost every hepatocyte over the whole liver acinus, and higher NEFA values. At day 45 in postpartum, both groups had mild steatotic changes as initially. A positive correlation between severity of liver damage seric and only aspartate aminotransferase was observed at day 140 in starved animals $(\mathrm{P}<0.05)$. This enzyme could be used to assess liver damage, but not alkaline phosphatase. All samples with degeneration corresponded to the microvesicular type. A short starvation period during late pregnancy in ewes produced reversible liver degeneration.
\end{abstract}

Keywords: ewe, liver biopsy, microvesicular steatosis, pregnancy toxemia

\section{RESUMO}

Caraterizaram-se histologicamente as alterações do fígado de ovelhas com toxemia da prenhez. Dez ovelhas foram mantidas em pasto ad libitum, e outras 10 submetidas a jejum a partir do $130^{\circ}$ dia de gestação, por até quatro dias. Biopsias hepáticas foram realizadas aos 70, 100, 130 e 140 dias de gestação e, aos 45 dias pósparto. Niveis séricos de hydroxibutirato, ácidos graxos não esterificados (NEFA), aspartato aminotransferase e fosfatase alcalina foram determinados. O estudo histológico revelou extensão semelhantes de degeneração nos dois grupos no $130^{\circ}$ dia de gestação. No $140^{\circ}$ dia de gestação, alta proporção de animais submetidos ao jejum, apresentou intensa degeneração no fígado (9/9 vs. 4/10; P<0,01) e, desses, quase todos 7/9 tinham grande quantidade de pequenas gotas de lipídios em quase todos os hepatócitos, nas diferentes regiões do ácino, além de níveis séricos mais elevados de NEFA. Quarenta e cinco dias pós-parto, os animais dos dois grupos apresentaram degeneração discreta, como no início. No $140^{\circ}$ dia de gestação, verificou-se correlação positiva entre a severidade das lesões histológicas e a enzima aspartato aminotransferase, nos animais submetidos a jejum $(P<0.05)$. Todas as amostras com degeneração corresponderam ao tipo microvesicular. Um curto período de jejum, na fase final da gestação da ovelha produz degeneração hepática reversível.

Palavras-chave: ovelha, biopsia hepática, esteatose microvesicular, toxemia da prenhez

\section{INTRODUCTION}

Ovine pregnancy toxemia is a common metabolic disorder of undernourished ewes due to increased fetal energy requirements in late pregnancy (Sargison et al., 1994). As fetal demand of glucose exceeds dietary energy intake, increased lipolysis lead to an augmented synthesis of ketone bodies (specially

Recebido em 28 de outubro de 2008

Aceito em 18 de março de 2009

E-mail: luiscalper@gmail.com 
hydroxybutyrate) to maintain metabolic homeostasis (Pethick and Lindsay, 1982; Sargison et al., 1994).

Available information about pregnancy toxemia focus mainly on pathogenic mechanisms and clinical features (Reid, 1968; Wastney et al., 1983; Marteniuk, 1988; Andrews, 1997), early diagnosis (Sargison et al., 1994; Scott et al., 1995), and therapeutic options (Wierda et al., 1985; Buswell et al., 1986; Marteniuk and Herdt, 1988; El-Hamamsy et al., 1990).

Reports about histopathological findings in this disease are referred to data obtained from post mortem examination. Cerebral and cerebellar neuronal necrosis and vacuolation, early structural maturity of placenta, and liver steatosis were found by different authors (Snook, 1939; Mitchell and Stratford, 1987; Marteniuk and Herdt, 1988; Jeffrey and Higgins, 1992; Andrews, 1997). It was suggested that fatty liver due to lipolysis interferes with hepatic gluconeogenic capacity, thus ketosis and fatty liver disease would play a central role in pregnancy toxemia (Herdt, 2000). Although being a rather commonly studied disease, no previous work assessing the evolution of histological changes of the liver during pregnancy toxemia and during the recovery period was found.

The aim of this work was to characterize the evolution of histological changes of the liver in ewes induced to pregnancy toxemia by the puncture biopsy method. It was also investigated the association of these changes with seric enzymatic activity of aspartate aminotransferase and alkaline phosphatase to consider them as possible prognostic indicators of hepatic damage in this disease.

\section{MATERIAL AND METHODS}

This study was carried out from March to August 2003 at the Experimental Station of the Facultad de Veterinaria, Universidad de la República, Uruguay.

Twenty four to six-year old Corriedale ewes were maintained on a paddock and treated 14 days with intravaginal devices of 50mg medroxyprogesterone acetate $^{1}$ for synchronization. After that, two fertile rams were introduced in the paddock and the mating date was considered as day 0 of pregnancy, which was confirmed by ultrasonography at day 70. All ewes carried singleton pregnancy and were fed on natural grasses until be randomly distributed in two groups when reached 130 days of pregnancy: ewes in Group A $(\bar{x}=54.8 \mathrm{~kg}, \mathrm{SD}=$ 6.6) continued to graze on the paddock, whilst ewes in Group B $(\bar{x}=53.3 \mathrm{~kg}, \mathrm{SD}=7.1)$ were enclosed in a pen and starved with free access to drinking water only for a period up to four days. After that, ewes were returned to the paddock and fed ad libitum, but those with neurological signs (clinical pregnancy toxemia) were excluded from the protocol and orally administered $100 \mathrm{~mL}$ of propylene glycol twice daily (Wierda et al., 1985). This experimental procedure was approved by the Animal Experimentation Committee of the Universidad de la República, Uruguay.

All ewes were bled at days 70, 100, 130, and 140 of pregnancy and 60 days afterwards, for dosification of serum aspartate aminotransferase (AST) and alkaline phosphatase (AP). Needle liver biopsies were done after blood sampling following the technique of Ferreira et al. (1996). Obtained samples weighed $14.9 \pm 10.5 \mathrm{mg}$. They were immediately fixed in $10 \%$ buffered formalin, and routinely processed for histological examination, sectioned at $5 \mu \mathrm{m}$ and stained with hematoxylin and eosin. From days 130 to 140 of pregnancy, both groups were daily bled for nonesterified fatty acids (NEFA) and 3hydroxybutyrate (HB) assays with commercial kits $^{2}$. AST and NEFA analysis were done within two hours of serum collection, and samples for $\mathrm{AP}$ and $\mathrm{HB}$ dosifications were stored at $-20^{\circ} \mathrm{C}$ until processed.

Biopsy preparations were coded to prevent the observer to bias the diagnosis, and at least three microscope fields of each sample were observed. The extent of degeneration was evaluated at 200x power magnification taking the liver acinus as a structural unit, considering peripheral, midzonal, and centrilobular localizations: zones I to III, respectively. The severity of cellular

\footnotetext{
${ }^{1}$ Sincrovin - Santa Elena Laboratorios - Montevideo,

Uruguay.

${ }^{2}$ Randox Laboratorios Ltda. -.Antrim, UK.
} 
vacuolar degeneration was evaluated at 400x power magnification and scored according to Stockhaus et al. (2004): $1=$ small amounts in a minority of cells, $2=$ variable amounts in a majority of cells, and $3=$ large amounts in almost every hepatocyte.

Within and between-group differences in serum enzyme and metabolite levels at each sampling day were compared with $t$ test for dependent and independent samples, respectively. Fraction of ewes with degeneration in each group was compared with Fisher's exact test. Associations between relative weight gain, AST, and AP with the degree of vacuolation were tested using Spearman r (rs) (Siegel, 1956). Simple linear regressions between seric NEFA levels and relative weight gain of all ewes were calculated for each sampling day. Relative weight gain of ewes was calculated as [ $(\mathrm{kg}$ body mass at day 130 - $\mathrm{kg}$ body mass at day 140)/kg body mass at day $130 \mathrm{x}$ 100]. Analysis were done with Statistica 5.0 software and significative differences were considered when $\alpha<0.05$. Values in the text were given as $\bar{x} \pm \mathrm{SD}$.

\section{RESULTS AND DISCUSSION}

Ewes live weight significantly varied within groups from days 130 to 140 of pregnancy, increasing from $54.8 \pm 6.6$ to $56.4 \pm 6.9 \mathrm{~kg}$ in Group A $(\mathrm{t}=4.1$, df $9, \mathrm{P}<0.01)$, but decreasing from $53.3 \pm 7.1$ to $45.0 \pm 6.4 \mathrm{~kg}$ in Group B $(\mathrm{t}=23.1$, df 9, $\mathrm{P}<0.0001)$. The differences in live weight between groups became significant at day 140 $(\mathrm{t}=3.9, \mathrm{P}<0.01$, df 18$)$. Relative live weight gain of all ewes was positively associated with NEFA levels $\left(\mathrm{R}^{2}=0.72, \mathrm{P}<0.01, \mathrm{n}=19\right)$ and inversely correlated with the degree of vacuolation ( $\mathrm{rs}=$ $0.74, \mathrm{P}<0.001, \mathrm{n}=19)$, only at day 140 .

In Group A, values of NEFA, HB, and AST did not significantly vary during the experiment, and ranged from 0.38 to $0.62 \mathrm{mmol} / \mathrm{L}, 0.1$ and $0.5 \mathrm{mmol} / \mathrm{L}$, and from 68 to $116 \mathrm{IU} / \mathrm{L}$, respectively. In group $\mathrm{B}$, NEFA values significantly increased at day 132 of pregnancy, from $0.37 \pm 0.25$ to $0.71 \pm 0.37 \mathrm{mmol} / \mathrm{L}(\mathrm{t}=3.08$; $\mathrm{P}<0.05$, df 5). The same was observed for $\mathrm{HB}$ on the following day, increasing from $0.40 \pm 0.20$ to $2.73 \pm 1.11 \mathrm{mmol} / \mathrm{L}(\mathrm{t}=3.3, \mathrm{P}<0.05$, df 5$)$. NEFA and $\mathrm{HB}$ continued significantly higher in this group from day 130 up to day 139. Maximum NEFA concentrations at day 135, and HB concentrations at day 138 were $1.90 \mathrm{mmol} / \mathrm{L}$ and $5.27 \mathrm{mmol} / \mathrm{L}$, respectively. Serum HB values during starvation were above minimum levels usually considered as diagnostic of clinical and naturally occurring pregnancy toxemia (Wierda et al., 1985; Cantley et al., 1991; Scott et al., 1995). Four days of starvation were severe enough to detect large amounts of circulating $\mathrm{HB}$, similarly to what was reported for experimentally induced pregnancy toxemia (West, 1996). By the end of the starving period, five animals of Group B were excluded from the experiment because of neurological signs of toxemia.

Histological preparations revealed similar liver degeneration incidence, extension, and severity in both groups at day 130 of pregnancy. At this stage, the majority of the affected ewes had poorly extended degeneration (acinus zone I) and scarce vacuolation (grade 1). Non-starved ewes of Group A remained largely unchanged during the experiment, and the mild steatotic changes observed in these animals seem to be a normal feature during late pregnancy (Rook, 2000). However, enhanced lipidic mobilization in starved animals would have caused a higher incidence of liver degeneration, and with higher degree of vacuolation which was significantly enhanced at the end of the starving period (all nine ewes in Group B vs. four out of ten in Group A; P<0.01, Fisher's exact test) (Table 1). In almost all starved ewes, acinus zones I, II, and III were affected, and with highest grade of vacuolation at this stage. Sixty days after starvation (approximately 45 days after parturition) animals of Group B returned to similar histological features as initially. All samples with degeneration diagnosis of both groups corresponded to the microvesicular type (Fig. 1 and 2), and alterations such as steatohepatitis or necrosis were not detected. 
Histological changes of the liver...

Table 1. Number of ewes with liver degeneration, localization and the corresponding degree of cellular vacuolation ( 1 to 3 from mild to severe)

\begin{tabular}{|c|c|c|c|c|}
\hline Day of pregnancy & Group & $\begin{array}{l}\text { Presenting } \\
\text { degeneration }\end{array}$ & Acinus localization & $\begin{array}{l}\text { Cellular } \\
\text { vacuolation }\end{array}$ \\
\hline \multirow{3}{*}{70} & $\mathrm{~A}(\mathrm{n}=10)$ & 2 & I & 1 \\
\hline & $\mathrm{B}(\mathrm{n}=10)$ & 2 & I & 1 \\
\hline & $\mathrm{A}(\mathrm{n}=10)$ & 4 & I & 1 \\
\hline \multirow[t]{2}{*}{100} & & & 2 in I & 1 \\
\hline & $B(n=10)$ & 3 & 1 in I to III & 2 \\
\hline \multirow[t]{3}{*}{130} & $\mathrm{~A}(\mathrm{n}=10)$ & 3 & I & 1 \\
\hline & $\mathrm{B}(\mathrm{n}=10)$ & 4 & 3 in I & 1 \\
\hline & & & $1 \mathrm{in} \mathrm{I} \mathrm{to} \mathrm{III}$ & 2 \\
\hline \multirow[t]{5}{*}{140} & $\mathrm{~A}(\mathrm{n}=10)$ & $4^{*}$ & 3 in I & 1 \\
\hline & & & $1 \mathrm{in} \mathrm{I} \mathrm{to} \mathrm{III}$ & 2 \\
\hline & $\mathrm{B}(\mathrm{n}=9)^{1}$ & 9 & 1 in I & 1 \\
\hline & & & 1 in I and II & 3 \\
\hline & & & 7 in I to III & 3 \\
\hline \multirow[t]{2}{*}{60 days afterwards } & $\mathrm{A}(\mathrm{n}=10)$ & 3 & I & 1 \\
\hline & $\mathrm{B}(\mathrm{n}=5)^{2}$ & 2 & I & 1 \\
\hline
\end{tabular}

Group A: controls; group B: starved from days 130 to 140 of pregnancy. I: peripheral; II: midzonal; III: centrolobular.

*Significantly less than group B ( $\mathrm{P}<0.01$; Fisher's exact test). ${ }^{1}$ Biopsy from one example discarded because of fixation artifacts. ${ }^{2}$ Five ewes out of protocol because of clinical pregnancy toxemia.

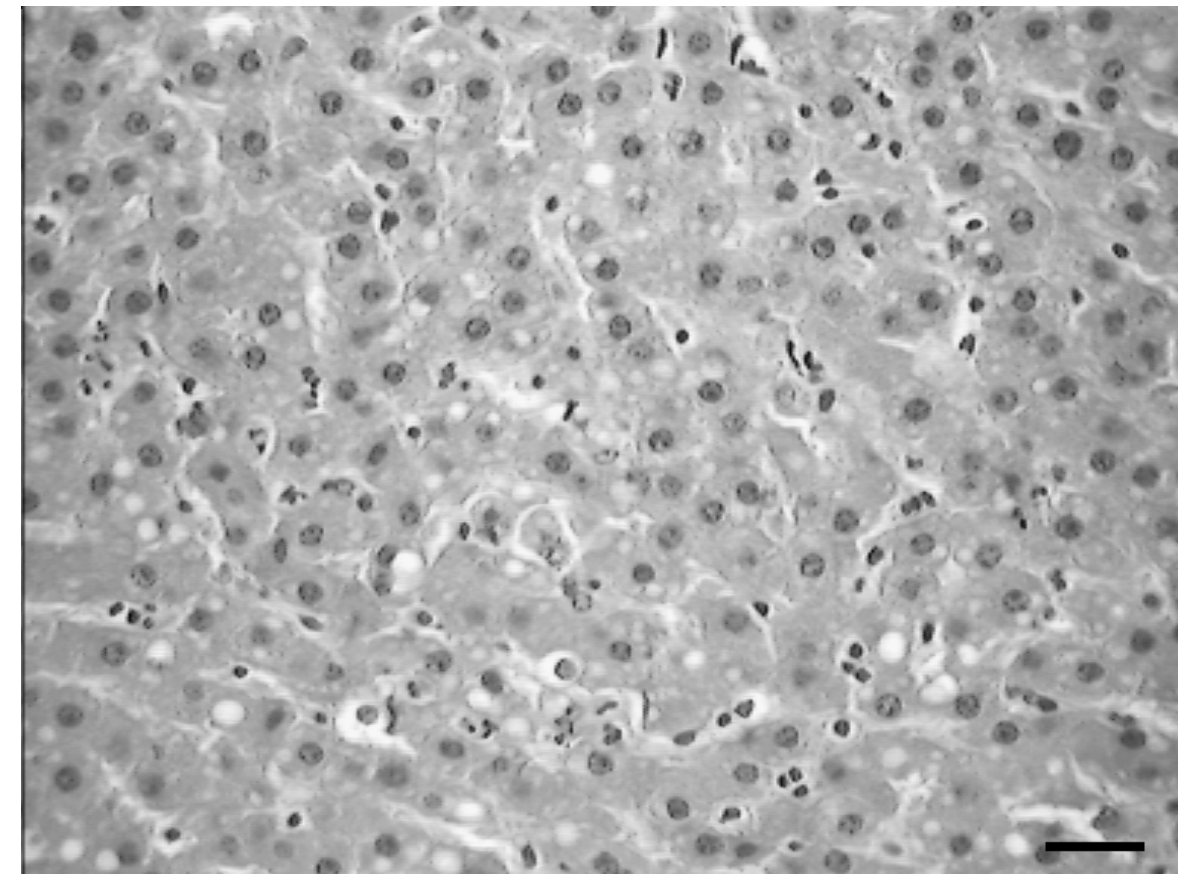

Figure 1. Ewe liver. View of hepatocyte cords with microvesicular degeneration, variable amounts of small lipid droplets in the majority of cells. Scale bar $=10 \mu \mathrm{m}$. 


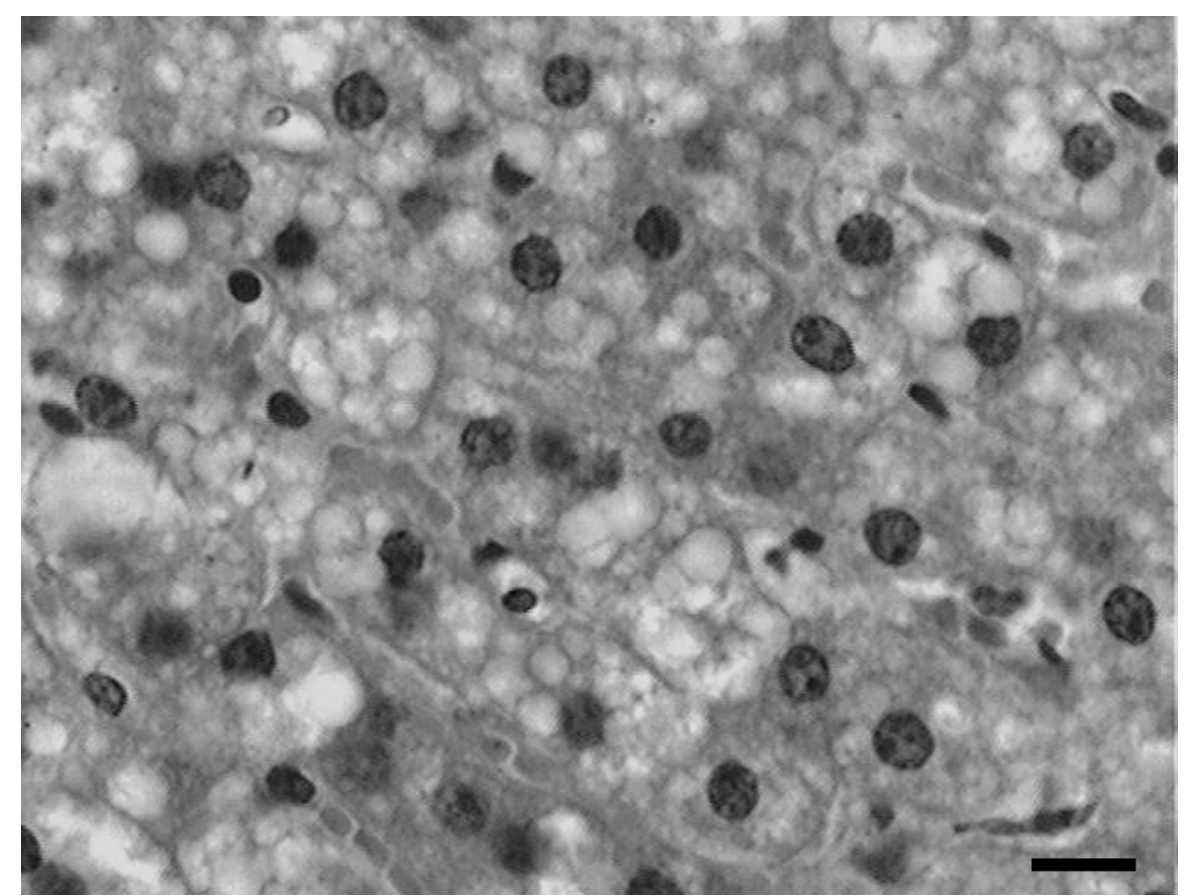

Figure 2. Ewe liver. Severe liver microvesicular degeneration, large amounts of lipid droplets in almost every hepatocyte. Scale bar $=20 \mu \mathrm{m}$.

Previous reports about ovine pregnancy toxemia are based on post mortem examination and do not give details about the histological aspect of the liver (Mitchell and Stratford, 1987; Marteniuk and Herdt, 1988; Jeffrey and Higgins, 1992; Andrews, 1997), except for Snook (1939). This author, who studied liver biopsies in toxemic ewes, mentioned the following about one of the studied animals ".....it can be seen that in many of the cells the protoplasm appears to have been almost entirely replaced by fat, the nucleus being pushed up against the cell wall" (Snook, 1939). This description and the corresponding illustration given by Snook (1939) fit into the macrovesicular type of steatosis and were obtained from a slaughtered ewe that was comatose due to pregnancy toxemia. In agreement with Snook (1939), degenerative changes or necrosis of the liver parenchyma were not observed, but hepatic degeneration during late pregnancy in toxemic ewes was of microvesicular type. Acute starvation can cause microvesicular degeneration due to fatty acid accumulation, and the sudden onset of mitochondrial dysfunction do not allow sufficient time for a progressive coalescence of tiny lipid droplets into the large fat inclusions seen in macrovesicular steatosis (Jaeschke et al., 2002).
The accumulation of lipids in the steatotic liver may have produced a severe impairment of mitochondrial beta-oxidation of fatty acids, and thus microvesicular steatosis as proposed by Fromenty and Pessayre (1995). Microvesicular steatosis has been reported in other pathologic conditions of ewes affecting mitochondrial metabolism, such as cobalt deficiency (Kennedy et al., 1997). Similarly, acute fatty liver during late pregnancy in humans is characterized by microvesicular steatosis (Fromenty and Pessayre, 1995; Burt, 2001). The mild steatotic changes observed in the liver of ewes that recovered from pregnancy toxemia, suggests that fatty liver with microvesicular steatosis can be reversed if treated. Microvesicular steatosis in humans is known to be reversed when energy metabolism returns to normality (Jaeschke et al., 2002), and also patients suffering fatty liver during pregnancy can recover from this condition with no long-term damage to the liver (Burt, 2001). It was reported that human fibroblasts with genetic defects of fatty acid oxidation developed microvesicular steatosis when transferred to a glucose-free media simulating clinical starving, but this was reversed with the addition of glucose (Renaud et al., 2002). 
At day 130 of pregnancy, detected seric activity of AST in animals of Group A was $89.1 \pm 22.2 \mathrm{IU} / \mathrm{L}$, which did not differ from what

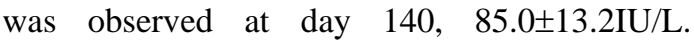
Corresponding values in animals of Group B at day 130 were not significantly different, $84.7 \pm 11.9$ IU/L. However, both groups differed in AST seric activity at the end of the starving period (day 140), in which AST increased to $331 \pm 152.1 \mathrm{IU} / \mathrm{L}$ in animals of Group B $(\mathrm{t}=2.69$, $\mathrm{P}<0.01$, df 18). A positive correlation was observed between AST (considering <100, 100200 , and $>200 \mathrm{IU} / \mathrm{L}$ intervals) and the degree of vacuolation in the liver only at day 140 ( $\mathrm{rs}=0.57$, $\mathrm{P}<0.05$ ), suggesting that this enzyme would be a useful and rapid indicator of liver damage in toxemic ewes. Andrews (1997) mentioned that changes in seric activity of aspartate aminotransferase and glutamate dehydrogenase would indicate liver damage in ovine pregnancy toxemia, but did not correlate them with liver histological changes.

Wierda et al. (1985) reported that serum activities of sorbitol dehydrogenase and gamma glutamyl transferase may be used as prognostic metabolites in this disease, instead of lactate dehydrogenase and alkaline phosphatase. In agreement with this author, no significant correlation of AP with the degree of vacuolation was observed. Seric activity of this enzyme did not significantly differ between groups, ranging from 38 to 197, and from 39 to 195UI/L from days 130 to 140 in Groups A and B, respectively. Alkaline phosphatase seem not to be useful for indirect assessment of liver steatosis severity in ewes undergoing pregnancy toxemia, contrary to what was suggested by Sargison et al. (1994).

It is concluded that a short starvation period during late pregnancy in ewes can produce liver microvesicular degeneration, which could affect the whole liver acinus and can be spontaneously reversed. Severity of liver damage was found to be associated to an increased seric activity of AST.

\section{ACKNOWLEDGMENTS}

Authors acknowledge Bruno López Leiro for his assistance during fieldwork. Franklin RietCorrea and José Manuel Verdes kindly reviewed an early version of the manuscript. Francisco
Kolenc and Graciela Duarte assisted in manuscript preparation, and José Manuel Venzal provided bibliography. This work was funded by Comisión Sectorial de Investigación Científica (CSIC), Universidad de la República, Uruguay.

\section{REFERENCES}

ANDREWS, A. Pregnancy toxaemia in the ewe. In Practice, v.19, p.306-312, 1997.

BURT A.D. Steatosis and steatohepatitis. Curr. Diagn. Pathol., v.7, p.141-147, 2001.

BUSWELL, J.F.; HADDY, J.P.; BYWATER, R.J. Treatment of pregnancy toxaemia in sheep using a concentrated oral rehydration solution. Vet. Rec., v.118, p.208-209, 1986.

CANTLEY, C.E.L.; FORD, C.M.; HEALTH, M.F. Serum fructosamine in ovine pregnancy toxaemia: a possible prognostic index. Vet. Rec., v.128, p.525-526, 1991.

EL-HAMAMSY, H.T.; EL-NEWEEHY, T.K.; ABDOU, O.M. et al. Clinical significance of oesophageal groove vasopresin induced-closure. A new concept in the oral glucose treatment of pregnancy toxaemia in ewes. Vet. Med. J., v.38, p.373-378, 1990.

FERREIRA, A.V.; VAN DER MERWE, H.; SLIPPER, S. A technique for obtaining liver biopsies from mature sheep. Small Rumin. Res., v.22, p.89-92, 1996.

FROMENTY, B.; PESSAYRE, D. Inhibition of mitochondrial beta-oxidation as a mechanism of hepatotoxicity. Pharmacol. Ther., v.6, p.101154, 1995.

HERDT, T.H. Ruminant adaptation to negative energy balance. Vet. Clin. N. Am. Food Anim. Pract., v.16, p.215-230, 2000.

JAESCHKE, H.; GORES, G.J.; CEDERBAUM, A.I. et al. Mechanisms of Hepatotoxicity. Toxicol. Sci., v.65, p.166-176, 2002.

JEFFREY, M.; HIGGINS, R.J. Brain lesions of naturally occurring pregnancy toxaemia of sheep. Vet. Pathol., v.29, p.301-307, 1992.

KENNEDY, S.; McCONNELL, S.; ANDERSON, H. et al. Histopathologic and ultrastructural alterations of white liver disease in sheep experimentally depleted of cobalt. Vet. Pathol., v.34, p.575-584, 1997. 
MARTENIUK, J.V.; HERDT, T.H. Pregnancy toxemia and ketosis of ewes and does. Vet. Clin. N. Am. Food Anim. Pract., v.4, p.307-315, 1988.

MITCHELL, G.M.; STRATFORD, B.F. The morphology of the ovine placenta in pregnancy toxaemia. Aust. Vet. J., v.64, p.221-223, 1987.

PETHICK, D.W.; LINDSAY, D.B. Metabolism of ketone bodies in pregnant sheep. Br. J. Nutr., v.48, p.549-563, 1982.

REID, R.L. The physiopathology of undernourishment in pregnant sheep, with particular reference to pregnancy toxaemia. In: BRANDLY, C.A.; CORNELIUS, C.E. (Eds). Advances in veterinary science. New York, London: Academic Press, 1968. v.12, p.163-238.

RENAUD, D.L.; EDWARDS, V.; WILSON, G.J. et al. Glucose-free medium exacerbates microvesicular steatosis in cultured skin fibroblasts of genetic defects of fatty acid oxidation. A novel screening test. J. Inherit. Metab. Dis., v.25, p.547-555, 2002.

ROOK, J.S. Pregnancy toxemia of ewes, does and beef cows. Vet. Clin. N. Am. Food Anim. Pract., v.16, p.293-317, 2000.

SARGISON, N.; SCOTT, P.; PENNY, C. et al. Plasma enzymes and metabolites as potential prognosis indices of ovine pregnancy toxaemia. A preliminary study. Br. Vet. J., v.150, p.271$276,1994$.
SCOTT, P.; SARGISON, N.; PENNY, C. et al. Cerebrospinal fluid and plasma glucose concentrations of ovine pregnancy toxaemia cases, inappetant ewes and normal ewes during late pregnancy. Br. Vet. J., v.151, p.39-44, 1995.

SIEGEL, S. Nonparametric statistics for the behavioral sciences. New York: Mc Graw-Hill, 1956. 312p.

SNOOK, L.C. Fatty infiltration of the liver in pregnant ewes. J. Physiol., v.97, p.238-249, 1939.

STOCKHAUS, C.; VAN DEN INGH, T.; ROTHUIZEN, J. et al. A multistep approach in the cytologic evaluation of liver biopsy samples of dogs with hepatic diseases. Vet. Pathol., v.41, p.461-470, 2004.

WASTNEY, M.E.; WOLTF, J.E.; BICKERSTAFFE, R. Glucose turnover and hepatocyte glucose production of starved and toxaemic pregnant sheep. Aust. J. Biol. Sci., v.36, p.271-284, 1983.

WEST, H.J. Maternal undernutrition during late pregnancy in sheep. Its relationship to maternal condition, pregnancy length, hepatic physiology and glucose metabolism. Br. J. Nutr., v.75, p.593-605, 1996.

WIERDA, A.; VERHOEFF, J.; VAN DIJK, S. et al. Effects of trampoline acetate and propylene glycol on pregnancy toxaemia in ewes. Vet. Rec., v.116, p.284-287, 1985. 